Volume 10. Nomor 2. December 2015
Pandecta
htt/journal.unnes.ac.id/nju/index.php/pandecta

\title{
Pengaturan Aborsi Korban Perkosaan Berbasis pada Prinsip Maslahah
}

\author{
Rohidin $\bowtie$ \\ Fakultas Hukum Universitas Islam Indonesia, Yogyakarta, Indonesia \\ Permalink/DOI http://dx.doi.org/10.15294/pandecta.v10i2.
}

\section{Info Artikel \\ Article History: \\ Received : August 2015; \\ Accepted: September 2015; \\ Published: September 2015}

\section{Keywords:}

abortion, rape, maslahah concepts, health law

\begin{abstract}
Abstrak
Pengaturan aborsi bagi korban perkosaan di Indonesia telah diatur dalam UU No. 36 Tahun 2009 tentang Kesehatan. Di dalamnya dikatakan bahwa setiap orang dilarang melakukan aborsi, namun larangan tersebut tidak berlaku jika ada indikasi kedaruratan medis, seperti kesehatan ibu dan janin terancam, atau kehamilan dalam kasus perkosaan. Penelitian ini bertujuan untuk menganalisis prinsip-prinsip hukum aborsi bagi korban yang diatur dalam UU Nomor 36 Tahun 2009 dilihat dari perspektif masalah yang digagas oleh Attufi. Hasil penelitian ini menunjukkan bahwa secara prinsipil materi hukum aborsi bagi korban perkosaan yang diatur dalam UU No. 36 Tahun 2009 tentang Kesehatan sejalan dengan konsep maslahah yang digagas oleh Attufi. Namun demikian, adanya batasan usia kehamilan maksimal enam minggu dihitung dari hari pertama haid terakhir menjadi hal yang menyebabkan undang-undang tersebut tidak lagi sejalan dengan konsep maslahah attufi. Ketidakselarasan ini disebabkan adanya kemungkinan kondisi psikis yang dialami oleh perempuan hamil korban perkosaan yang mengakibatkan ketidaktahuan awal kehamilan. Dalam arti, bisa jadi perempuan tersebut baru mengetahui kehamilannya melebihi batas waktu tersebut. Namun demikian, kebolehan ini juga harus melalui pertimbangan-pertimbangan perbandingan kemaslahatan dan kemafsadatan yang ada sesuai dengan kasusnya masing-masing.
\end{abstract}

\begin{abstract}
The abortion regulation for rape victims in Indonesia has been regulated in Law No. 36 Year 2009 on Health. It is said that every person is prohibited from having an abortion, but the restriction does not apply if there is an indication of a medical emergency, such as maternal and mother health is threatened, or the pregnancy in cases of rape. This study aims to analyze the principles of legal abortion for victims as stipulated in Law No. 36 of 2009 seen from the perspective of the Masalahah initiated by Attufi. The results showed that in principle the material legal abortions for rape victims as stipulated in Law No. 36 Year 2009 on Health in line with the concept of maslahah initiated by Attufi. However, the maximum age limit of six weeks of pregnancy calculated from the first day of the last menstrual period into the cause of the law is no longer in line with the concept of maslahah attufi. This misalignment is due to the possibility of psychological conditions experienced by pregnant women victims of rape resulting in early pregnancy ignorance. In a sense, it could be the woman learned of her pregnancy exceeding the time limit. However, this ability should also go through the considerations and harms ratio that is in accordance with each case.
\end{abstract}




\section{Pendahuluan}

Fenomena perkosaan merupakan bagian dari tindak kekerasan seksual. Di Indonesia, kasus tersebut berbanding lurus dengan fenomena aborsi itu sendiri, dalam arti sama-sama maraknya (Amnesty Internasional, 2010, 8-9; Utomo, dkk., 200). Bahkan, akhir-akhir ini gencar diberitakan bahwa perkosaan sering dilakukan di tempat-tempat umum, seperti dalam angkutan umum (Republika, 22 November 2011). Lembaga Rifka Annisa yang berkantor di Yogyakarta mempublish dalam situs resminya bahwa pada tahun 2000-2003 menerima pengaduan perkosaan rata-rata 250 kasus di setiap tahunnya (Rifka Anisa Web, 2011). Lebih jauh, Komnas Perempuan melaporkan bahwa dari tahun 1998 hingga 2010 sejumlah 8.326 kasus kekerasan seksual telah terjadi. Dari jumlah tersebut, jenis kasus perkosaan menempati urutan tertinggi, yakni 4.391 kasus, sementara kasus percobaan perkosaan mencapai 109 kasus (Tim Partisipasi Masyarakat, 2011).

Estimasi tersebut bukanlah data sesungguhnya yang terjadi di lapangan. Masalahnya, banyak korban perkosaan tidak bersedia untuk melaporkan kepada PihakKepolisian karenastigma negatifyang akan ia terima. Lebih dari itu, perempuan korban perkosaan sering menjadi objek yang dipersalahkan. Dalam pada itu, diakui atau tidak, di antara sejumlah kasus tersebut terdapat kasus-kasus perkosaan hingga mengakibatkan kehamilan (Suara Merdeka, 8 Januari 2011). Di sinilah letak urgensitas diangkatnya topik aborsi bagi korban perkosaan dalam tulisan ini. Pertanyaanya kemudian manakah yang lebih diutamakan antara haknya dan hak hidup si janin? Legalkah jika ia melakukan aborsi sebagai bentuk pemenuhan haknya? Jika memang legal, bagaimana ketentuannya?

Di Indonesia, aborsi bagi korban perkosaan pada dasarnya telah diatur oleh beberapa ketentuan perundang-undangan. Di antaranya adalah Kitab Hukum Pidana (KUHP) Pasal 283, 299, 346, 348, 349, dan 535, serta Undang-undang (UU) No. 23 Tahun 1992 Tentang Kesehatan Pasal 15 dan 80. Pada ta- hun 2009, UU No. 23 Tahun 1992 diamandemen dengan UU No. 36 Tahun 2009. Di dalamnya juga termasuk mengamandemen pasal-pasal yang mengatur tentang aborsi bagi korban perkosaan, yakni melalui Pasal 75, 76, dan 77. Pasca-disahkannya UU No. 36 Tahun 2009 ini, serta dikeluarkannya Peraturan Pemerintah Nomor 61 Tahun 2014, perbincangan boleh dan tidaknya aborsi secara umum dan dari Kehamilan yang Tidak Dikehendaki (KTD) akibat perkosaan kerap diperbincangkan.

Dalam konteks pengaturan aborsi, materi undang-undang tersebut menuai kontroversi yang berkepanjangan. Di satu pihak dianggap memasung kebebasan perempuan dan di sisi yang lain juga terdapat sekelompok kecil yang menganggap sebagai bentuk ketidakhormatan kepada manusia. Di antara dua pandangan tersebut, tidak sedikit juga masyarakat yang mendukung adanya undang-undang tersebut. Cara pandang yang digunakan oleh masing-masing kelompok berbeda satu sama lain, seperti agama, Hak asasi Manusia (HAM), dan feminism (Muthmainnah, 2010; Matanews, 2009).

Istilah hukum Islam sendiri oleh masyarakat Muslim Indonesia identik dengan fikih itu sendiri. Artinya, jika terjadi praktik aborsi yang dibicarakan masyarakat adalah bagaimana fikih memandang itu. Padahal, sisi lain dari hukum Islam dapat berarti syariah, alQur'an dan hadis, bukan semata mata fikih. Sementara itu, Islam sendiri diturunkan oleh Allah melalui Muhammad dalam bentuk alQur'an hanya untuk kemaslahatan manusia. Dalam proses penurunannya yang bersifat gradual tidak terlepas dari adanya tujuan-tujuan (maqasid al-syari ah) yang ingin dicapai.

Konsep maslahah sendiri dipahami oleh para ahli secara beragam. Dalam penelitian ini, peneliti menggunakan konsep maslahah perspektif Najm al-Din al-Tufi (kemudian disebut al-Tufi). Pemilihan ini bukan tanpa alasan, tetapi lebih dikarenakan titik tekan al-Tufi atas rasionalitas manusia yang lebih diunggulkan dari pada teks keagamaan dalam aras konseptual maslahahnya. Inilah sisi perbedaan mașlahah al-Ṭūfĩ dengan rumusan mașlaḥah yang lain, seperti Abū Hāmid al-Gazalī (1980: 286), Abū Isḥāq al- 
Syāțibī (1973: II/8-12), dan Ibn al-Qayyim al-Jawziyyah (1973: 14). Penekanan rasionalitas manusia dalam konsep maslahah menjadi relevan mengingat fokus kajian penelitian ini adalah KTD akibat perkosaan, bukan KTD akibat kelalaian atau "kecelakaan" lain. Berdasarkan hal tersebut, artikel ini berupaya mengulas tentang bagaimana pengaturan aborsi bagi korban perkosaan dengan berbasis pada prinsip maslahah.

\section{Metode Penelitian}

Penelitian ini termasuk dalam kategori penelitian yang bersifat deskriptif-analisis berupa penggambaran tentang materi hukum aborsi bagi korban perkosaan di Indonesia. Karena itu pertama kali yang diurai dalam penelitian ini adalah gambaran umum tentang aborsi terkait dengan tinjauan definitif, macam aborsi dalam regulasi, dan pandangan intelektual Muslim terhadap kasus aborsi. Setelah semua aspek di atas dideskripsikan, selanjutnya akan dilakukan analisis untuk mengetahui bagaimana pengaturan aborsi bagi korban perkosaan di Indonesia ditinjau dari perspektif maslahat al-Tufi. Untuk menjawab permasalahan tersebut pendekatan yang digunakan adalah pendekatan perundang-undangan dan pendekatan konseptual. Pendekatan perundang-undangan dianggap relevan karena penelitian ini menganalisis pengaturan aborsi bagi korban perkosaan di Indonesia, sementara pendekatan konseptual digunakan untuk menganalisa struktur konseptual dari materi pengaturan tersebut dengan perspektif maslahah al-Tufi.

\section{Hasil Penelitian dan Pembahasan}

\section{Aborsi dalam Literatur}

Secara etimologi aborsi berasal dari bahasa Inggris, yaitu abortion dan dari bahasa Latin, yaitu abortus, yang artinya pengguguran kandungan, keluron (Jawa), keguguran (Hasan, 1998: 44). Sementara itu, aborsi dalam bahasa Arab diartikan al-ijhāọ, yang merupakan bentuk mașdar dari kata ajhaḍa, yang artinya lahirnya janin karena dipaksa atau lahir dengan sendirinya sebelum tiba saatnya (Mahjuddin, 2005: 76). Selain diartikan dengan istilah al-ijhāọ, aborsi juga diarti- kan para fuqahā dengan istilah isqāṭ (menjatuhkan), țarh (membuang), ilqā' (melempar), dan imlāș (melahirkan dalam keadaan mati) (Uddin, dkk., 2006:130).

Secara terminologi (istilāḥi)—mengutip penelitian dari Jurnalis Udin dkk., fuqahā memberikan definisi aborsi dengan redaksi berbeda, namun bermuara pada substansi yang sama. Ibrāhim al-Nakha '̄i mengatakan bahwa aborsi adalah pengguguran janin dari rahim ibu hamil, baik sudah berbentuk sempurna atau belum. Tidak jauh berbeda dengan al-Nakha'ī adalah definisi 'Abdullāh bin Ahmad, yang menyatakan bahwa aborsi adalah merusak mahluk yang ada dalam rahim perempuan. Demikian pula menurut 'Abdul Qadir Audah, di mana ia berpendapat bahwa aborsi adalah pengguguran kandungan dan perampasan hak hidup janin atau perbuatan yang dapat memisahkan antara janin dengan ibunya. Sedangkan bagi al-Gazalī, aborsi adalah pelenyapan nyawa janin atau merusak sesuatu yang sudah terkonsepsi (mawjūd al-hașil). (Uddin dkk., 2006: 131). Definisi aborsi lebih detail terurai dalam Grolier Family Encyclopedia. Sebagaimana dikutip Khairuddin Nasution, aborsi didefinisikan dengan, "..is the termination of a pregnancy by loss or destruction of the fetus before birth. An abortion may be spontaneous or induced. The latter is an act with ethical and legal ramifications" (Nasution, 2003: 114; Uddin dkk., 2006: 130).

Berdasarkan segi kejadiannya, menurut Masjfuk Zuhdi, aborsi dapat dibagi menjadi dua macam, yaitu aborsi spontan dan aborsi buatan/disengaja (Zuhdi, 1986: 39). Aborsi spontan (abortus spontanea) adalah pengguguran secara tidak disengaja dan terjadi tanpa tindakan apapun. Pengguguran dalam bentuk ini lebih sering terjadi karena faktor di luar kemampuan manusia, seperti pendarahan dan kecelakaan. Pengguguran seperti ini tidak menimbulkan akibat hukum. Sementara aborsi buatan (abortus provocatus) adalah pengguguran yang terjadi sebagai akibat dari suatu tindakan. Aborsi dalam bentuk ini dapat dibedakan dalam dua macam, yaitu therapicus dan criminalis. Abortus provocatus therapicus adalah pengguguran yang dilakukan oleh dokter karena indikasi medis. Jika 
kehamilan diteruskan, maka akan membahayakan jiwa si calon ibu; karena ada penyakit berat, misalnya. Sementara abortus provocatus criminalis adalah pengguguran yang dilakukan tanpa dasar indikasi medis. Model yang terakhir ini dapat dicontohkan dengan aborsi yang dilakukan untuk meniadakan hasil hubungan seks di luar nikah atau untuk mengakhiri kehamilan yang tidak dikehendaki.

Menurut Syaltūț, sebagaimana yang dikutip oleh Jurnalis Udin dkk., aborsi berdasarkan sisi peniupan ruh ke dalam janin yang ada di dalam rahim ibunya, dapat dibedakan menjadi dua macam. Pertama, aborsi yang dilakukan sebelum peniupan ruh. Berkaitan dengan aborsi model ini, ulama berbeda pendapat, ada yang membolehkan dan ada yang melarang secara mutlak. Kedua, aborsi yang dilakukan sesudah peniupan ruh ke dalam janin. Berkaitan dengan aborsi model ini, jumhur ulama sepakat bahwa aborsi ini diharamkan, kecuali dalam keadaan darurat (Uddin dkk., 2006: 75).

\section{Pandangan Intelektual Muslim terhadap Aborsi}

Pandangan ulama kontemporer mengenai aborsi sebenarnya merupakan pengembangan dari pandangan para imam mazhab sebelumnya. Misalnya saja, Muḥammad Sallām Mażkūr dalam bukunya al-Janīn wa al-Ahkām al-Muta alliqah bih fī al-Fiqh alIslāmī (Bahss Muqāran). Dengan menguraikan pandangan dari beragam mazhab, ia menguatkan pendapat yang mengharamkan aborsi, baik sebelum ditiupkan ruh maupun sesudahnya. Begitu pun juga dengan Wahbah al-Zuhailī yang menguatkan pendapat al-Gazalī, ia menganggap sekalipun aborsi dilakukan sejak konsepsi tetap saja merupakan suatu kejahatan terhadap mahluk yang sudah tercipta. Kelonggaran disampaikan oleh Jāmil Mubārak ibn Mubārak, dia menguraikan bahwa jika terdapat keadaan darurat yang mengharuskan dilakukannya aborsi, maka dapat diberi dispensasi (rukhșah), dan jika tidak ada, maka tidak dibenarkan. Hukum ini berlaku, baik sebelum atau pun sesudah ditiupkannya ruh (Uddin, 2006: 134-135).

Pengharaman aborsi dalam semua fase kehidupannya-baik sebelum ataupun sesudah ditiupkan ruh-juga terdapat dalam sejumlah fatwa para muftī kontemporer. Misalnya saja Syaltūṭ dalam al-Fatawā, dengan mengutip pendapatnya al-Gazalī ia mengatakan bahwa sebenarnya kehidupan sudah ada sejak awal konsepsi, sehingga aborsi haram secara mutlak. Dengan alasan yang berbeda namun bermuara pada kesimpulan yang sama adalah pandangan Quraish Shihab. Dia mengungkapkan bahwa aborsi tidak ada bedanya dengan pembunuhan terhadap anak, karena keduanya-aborsi dan pembunuhan —sama-sama berdampak pada penghilangan nyawa yang telah siap untuk berpartisipasi dalam tugas kekhalifahan. Menurutnya, perdebatan mengenai aborsi selama ini lebih ditekankan pada kadar dosa dan sanksi hukum yang harus dikenakan kepada pelakunya, padahal permasalahan aborsi terkait dengan masalah etika. Oleh karena itu, dia berpendapat bahwa aborsi dilarang, meskipun belum berumur 120 hari, kecuali ada alasan-alasan medis (Uddin, 2006: 136-137).

Sementara itu, mengenai aborsi akibat perzinaan, Sa`īd Ramaḍān al-Būțī dengan tegas mengatakan bahwa aborsi dalam kasus ini hukumnya haram secara mutlak (Al-Būțī, 1965: 143). Hal ini dikarenakan janin tidak menanggung dosa ibunya dan ia tidak bersalah. Oleh karenanya, aborsi akibat perzinaan dipandang sebagai tindak kriminal yang berkaitan erat dengan moralitas social. Meskipun demikian, al-Būțī memberikan pengecualian, namun pengecualian tersebut hanya berlaku jika si ibu mendapat ancaman pembunuhan jika tidak melakukan aborsi. Maka, dalam kasus ini, aborsi diperbolehkan karena untuk menyelamatkan jiwa si ibu. Sementara aborsi dalam kasus perkosaan, al-Būțī memperbolehkan jika kelahiran anak tersebut dipastikan akan membawa dampak buruk bagi jiwa dan raga si ibu di kemudian hari. Aborsi untuk kasus ini diperbolehkan karena perempuan korban perkosaan bukanlah sebagai pelaku tindak pidana, sehingga rukhșah aborsi diberlakukan (Al-Būțī, 1965: 159-160).

\section{Tinjauan Umum Tentang Konsep Masla- \\ hah}

Konsep maslahah dalam term usul fiqih 
biasa disebut dengan mashlahah. Kata ini merupakan derivasi dari kata shalaha-yashlahu-shuluhan. Dalam bentuk masdar, ia memiliki arti sesuatu yang berkesesuaian dengan dan di dalamnya memiliki arti penting atau sesuatu yang mendatangkan nilai manfaat baik materi ataupun in-materi (Hāsyimah, 2003: 629). 'Izzuddīn bin `Abd al-Salām dalam karyanya, Qawāìi al-Aḥkām fĩ mașāliḥ al-Anām, menjelaskan bahwa makna literal dari mașlaḥah dan antonimnya, mafsadah, adalah suatu kebaikan dan keburukan, manfaat dan maḍarat, bagus dan jelek (al-Salam, 1994: 5).

Secara sederhana, mașlaḥah dalam tinjauan terminologis adalah upaya pengambilan manfaat dan pencegahan mafsadat (jalb al-mașālih wa daf' al-mafāsid) (Zayd, 1424: 22). Sementara jika dikaitkan dengan kepentingan manusia, mașlaḥah adalah aktivitas yang bertujuan untuk pemanfaatan dan pencegahan maḍarat dalam kehidupan manusia di dunia maupun di akhirat (al-Syāțibī, 1997: 3). Mașlaḥah sendiri dapat dikatakan sebagai salah satu unsur dalam syariah yang berhubungan langsung dengan manusia sebagai objeknya. Sehingga dapat dikatakan bahwa mașlaḥah adalah menjadi tujuan utama dan maksud ditetapkannya syariah di dunia dan di akhirat.

Pengertian-pengertian di atas juga sejalan dengan apa yang disampaikan oleh Jalāluddīn `Abd al-Raḥmān al-Suyūțī. Dalam al-Asybah wa al-Nażā'ir ia mengatakan bahwa bahwa dar' al-mafasid muqaddamun 'alā jalb al-mașāliḥ berarti menolak kerusakan (mafsadah) lebih utama dari pada menarik mașlahah (al-Suyutī, t.th.: 7). Dalam hal ini, al-mașlahah diartikan dengan pengambilan manfaat. la memberikan alasan demikian karena menghindari suatu kerusakan adalah berdampak besar terhadap keberlangsungan hidup manusia, sedangkan jalb al-mașālih merupakan pelengkap dan kewajiban hidup yang pada dasarnya menjahui ke-mafsadatan harus lebih dijaga agar dapat melaksanakan kebaikan secara maksimal (Hallaq, 2005: 65).

Salah satu metode yang dikembangkan oleh ulama ushul figh dalam meng-istinbātkan hukum dari naș (dalil) lewat pendekatan istișlāḥi adalah mașlaḥah mursalah. Dalam mașlahah mursalah suatu kemaslahatan yang tidak ada naș juz'î (rinci) yang mendukungnya, tidak ada yang menolaknya, dan tidak ada pula ijmā’ yang mendukungnya. Akan tetapi, kemaslahatan ini didukung oleh sejumlah naș dengan cara induksi dari sejumlah naș (Al-Syāțibī, 1997: 8-12). Pendekatan istișlāhī digunakan bila tidak ada dalil khusus yang berhubungan dengan kasus hukum baru sehubungan dengan kemajuan dan perkembangan zaman (Bakar, 1991: 23).

Al-Gazālī memandang bahwa suatu kemaslahatan harus sejalan dengan tujuan syar $i$, sekalipun bertentangan dengan tujuan manusia, karena kemaslahatan manusia tidak selamanya didasarkan kepada kehendak syar ' $i$, tetapi sering didasarkan pada hawa nafsu. Oleh sebab itu, yang dijadikan patokan dalam mentukan kemaslahatan itu adalah kehendak dan tujuan syar ï, bukan kehendak dan tujuan manusia. Kemaslahatan yang dapat dijadikan pertimbangan untuk menetapkan hukum menurut al-Gazālī adalah apabila; (1) mașlaḥah itu sejalan dengan tindakan syara', (2) mașlahah itu tidak meninggalkan atau bertentangan dengan naș syar ' ${ }^{\top}$, (3) mașlaḥah itu termasuk ke dalam kategori mașlaḥah yang ḍarūrī, baik yang menyangkut kemaslahatan pribadi maupun orang banyak dan universal, yaitu berlaku sama untuk semua orang (al-Gazālī, 1980: 286).

Mașlaḥah menurut Abū Isḥāq alSyāțibī dapat dibagi ke dalam dua segi. Pertama, dari segi kualitas dan kepentingan kemaslahatan. Segi ini terdapat tiga macam, yaitu: ḍarūriyyah, hājijyah, dan taḥsiniyah. Kemaslahatan jenis pertama berhubungan dengan kebutuhan pokok umat manusia di dunia dan di akhirat, yakni memelihara agama, jiwa, akal, keturunan, dan harta. Kelima kemaslahatan ini disebut dengan al-mașāliḥ al-khamsah. Kemaslahatan jenis kedua dibutuhkan untuk menyempurnakan atau mengoptimalkan kemaslahatan pokok (almașāliḥ al-khamsah) yaitu berupa keringanan untuk mempertahankan dan memelihara kebutuhan mendasar manusia (al-mașāliḥ al-khamsah) diatas. Sedangkan jenis kemaslahatan ketiga bersifat komplementer (pelengkap), berupa keleluasan dan kepatutan 
yang dapat melengkapi kemaslahatan sebelumnya (mașlaḥah hājiyah). Kedua, dari segi keberadaan mașlaḥah. Segi ini terdapat tiga macam, yaitu mu 'tabarah, mulgah, dan mursalah. Kemaslahatan jenis pertama didukung oleh dalīl syar'T. Artinya, terdapat dalil khusus yang menjadi dasar dari bentuk atau jenis kemaslahatan tersebut. Jenis kedua adalah kemaslahatan yang ditolak oleh dalil syar' $\bar{T}$, karena bertentangan dengan ketentuannya. Sedangkan jenis ketiga kemaslahatan yang keberadaannya tidak didukung oleh dalil syar ${ }^{\top} T$ dan tidak pula dibatalkan atau ditolak melalui dalil yang rinci, tetapi didukung oleh sekumpulan makna naș. Kemaslahatan dalam jenis ketiga ini terbagi lagi menjadi dua, yaitu garībah dan mursalah. Garỉbah adalah jenis kemaslahatan yang asing, atau kemaslahatan yang sama sekali tidak ada dukungan syar 'i, baik secara rinci maupun umum. Al-Syāțibī mengatakan kemaslahatan seperti ini tidak ditemukan dalam praktik, sekalipun ada dalam teori. Sedangkan mursalah adalah kemaslahatan yang tidak didukung dalil syar ${ }^{~} i$ atau naș yang rinci, tetapi didukung oleh sekumpulan makna naș (Al-Syāțibī, 1997: II/812).

Mayoritas ulama Ushul Fiqh (Hānafiyyah, Syāfì iyyah, Mālikiyyah dan Hanabilah) menetapkan bahwa mașlahah dapat dijadikan dalil untuk menetapkan hukum, apabila memenuhi tiga syarat. Pertama, kemaslahatan itu sejalan dengan kehendak syar $i$ dan termasuk dalam jenis kemaslahatan yang didukung naș secara umum. Kedua, kemaslahatan itu bersifat rasional dan pasti, bukan sekedar perkiraan sehingga hukum yang diterapkan melalui mașlahah mursalah itu benar-benar menghasilkan manfaat dan menghindari atau menolak kemudaratan. Ketiga, kemaslahatan itu menyangkut kepentingan orang banyak, bukan kepentingan pribadi atau kelompok kecil tertentu Al-Syāțibī, 1997: II/8-12; al-Jawziyyah, 1973: 14). Alasan Jumhur ulama Ushul Figh, di antaranya adalah: (a) hasil induksi terhadap ayat atau hadis menunjukkan bahwa setiap hukum mengandung kemaslahatan bagi umat manusia, (b) kemaslahatan manusia senantiasa dipengaruhi perkembangan tempat, zaman, dan lingkungan mereka sendiri, sementara apabila syariah Islam terbatas pada teks-teks hukum yang ada, akan membawa kesulitan, (c) merujuk kepada tindakan yang dilakukan oleh beberapa sahabat Nabi saw., antara lain 'Umar ibn al-Khațțāb tidak memberi zakat kepada para mu'allaf, karena kemaslahatan orang banyak menuntut hal itu (Al-Gazalī, 1980: 139 dan Al-Syāțibī, 1997: II/8-12).

Dalam pandangan al-Ṭūfī bahasan lafal mașlahah berdasarkan wazan maf'alatun dari bentuk kata kerja lampau șalaḥa. Artinya, sesuatu dibuat sedemikian rupa sesuai dengan kegunaannya. Sedangkan definisi mașlaḥah adalah sarana yang menyebabkan adanya mașlahah dan manfaat. Pengertian berdasarkan syariah adalah sesuatu yang menjadi penyebab untuk sampai kepada maksud Syāri', baik berupa ibadat maupun adat. Kemudian, mașlaḥah ini terbagi menjadi dua bagian, yaitu perbuatan yang memang merupakan kehendak Syāri', yakni ibadat dan apa yang dimaksudkan untuk kemanfaatan semua umat manusia dan tatanan kehidupan, seperti adat-istiadat (Al-Ṭūfi, t.th:: 25).

Al-Ṭūfĩ menganggap bahwa mașlaḥah hanya ada pada masalah-masalah yang berkaitan dengan mu amalah dan yang sejenis, bukan pada masalah-masalah yang berhubungan dengan ibadat atau yang serupa. Sebab, masalah ibadat merupakan hak preogratif Syārì. Tidak mungkin seseorang mengetahui hakikat yang terkandung di dalam ibadat, baik kualitas maupun kuantitas, waktu atau tempat, kecuali hanya berdasarkan petujuk resmi Syāri`. Kewajiban hamba hanyalah menjalankan apa saja yang telah diperintahkan oleh Tuhannya. Sebab, seseorang pembantu tidak akan dikatakan sebagai seorang yang taat jika tidak menjalankan perintah yang telah diucapkan oleh tuannya, atau mengerjakan apa saja yang sudah menjadi tugasnya. Demikian halnya dalam masalah ibadat. Karenanya, ketika para filosof telah mulai mempertuhankan akal, dan mulai menolak syariah, Allah swt. amat murka terhadap mereka. Mereka tersesat jauh dari kebenaran. Bahkan mereka sangat menyesatkan. Berbeda halnya dengan kaum mukallaf, hak-hak mereka di dalam memutuskan hukum adalah perpaduan antara siyasah dan syariah yang sengaja oleh pencipta 
dicanangkan untuk mașlaḥah umat manusia. Itulah yang menjadi ukuran berpikir mereka (Al-Ṭūfi, t.th.: 25).

Pandangan al-Ṭūfī tentang mașlaḥah nampaknya bertitik tolak dari konsep maqāșid al-tasyrī (al-syarīah) yang menegaskan bahwa hukum Islam disyariahkan untuk mewujudkan dan memelihara mașlaḥah umat manusia. Konsep ini telah diakui oleh para ulama dan oleh karena itu mereka memformulasikan suatu kaidah yang cukup populer, "Di mana ada mașlaḥah, di sana terdapat hukum Allah." (Al-Būțī, 1965: 12). Signifikansi ini membuat para pakar teori hukum menjadikan maqāșid al-syarī ah sebagai salah satu kriteria (di samping kriteria lainnya) bagi mujtahid yang melakukan ijtihad. Adapun inti dari konsep maqāșid al-syarīa ah adalah untuk mewujudkan kebaikan sekaligus menghindarkan keburukan atau menarik manfaat dan menolak mudarat, istilah yang sepadan dengan inti dari maqāșid al-syarīa ah tersebut adalah mașlaḥah, karena penetapan hukum dalam Islam harus bermuara kepada mașlaḥah.

\section{Legalitas Praktik Aborsi bagi Korban Perkosaan dalam UU No. 36 Tahun 2009 Tentang Kesehatan}

\section{a.Latar Belakang Pembentukan}

Dengan dikeluarkannya undang-undang kesehatan yang baru, yaitu UU No. 36 Tahun 2009, maka secara otomatis undangundang kesehatan yang lama, yaitu UU No. 23 Tahun 1992 sudah tidak berlaku lagi. Kemunculannya ini dilatarbelakangi oleh beberapa hal, salah satunya undang-undang kesehatan yang lama sudah tidak sesuai lagi dengan perkembangan, tuntutan, dan kebutuhan hukum dalam masyarakat. Latar belakang ini diungkapkan di dalam lampiran undang-undang kesehatan yang baru, khususnya pada bagian awal, yaitu bagian menimbang. Kesemua latar belakang pembentukan UU No. 36 Tahun 2009 tersebut ada enam hal, yang akan diliput sebagai berikut:

Pertama, bahwa kesehatan merupakan hak asasi manusia dan salah satu unsur kesejahteraan yang harus diwujudkan sesuai dengan cita-cita bangsa Indonesia se- bagaimana dimaksud dalam Pancasila dan Undang-Undang Dasar Negara Republik Indonesia Tahun 1945; Kedua, bahwa setiap kegiatan dalam upaya untuk memelihara dan meningkatkan derajat kesehatan masyarakat yang setinggi-tingginya dilaksanakan berdasarkan prinsip nondiskriminatif, partisipatif, dan berkelanjutan dalam rangka pembentukan sumber daya manusia Indonesia, serta peningkatan ketahanan dan daya saing bangsa bagi pembangunan nasional; Ketiga, bahwa setiap hal yang menyebabkan terjadinya gangguan kesehatan pada masyarakat Indonesia akan menimbulkan kerugian ekonomi yang besar bagi negara, dan setiap upaya peningkatan derajat kesehatan masyarakat juga berarti investasi bagi pembangunan negara; Keempat, bahwa setiap upaya pembangunan harus dilandasi dengan wawasan kesehatan dalam arti pembangunan nasional harus memperhatikan kesehatan masyarakat dan merupakan tanggung jawab semua pihak baik Pemerintah maupun masyarakat; Kelima, bahwa Undang-Undang Nomor 23 Tahun 1992 tentang Kesehatan sudah tidak sesuai lagi dengan perkembangan, tuntutan, dan kebutuhan hukum dalam masyarakat sehingga perlu dicabut dan diganti dengan Undang-Undang tentang Kesehatan yang baru; Keenam, bahwa berdasarkan pertimbangan sebagaimana dimaksud dalam huruf a, huruf b, huruf c, huruf d, dan huruf e perlu membentuk Undang-Undang tentang Kesehatan.

Dengan disahkannya UU No. 36 Tahun 2009 tentang Kesehatan menggantikan undang-undang kesehatan sebelumnya yaitu UU No. 23 Tahun 1992, maka permasalahan aborsi lebih memperoleh legitimasi dan penegasan. Secara eksplisit, dalam undang-undang kesehatan yang baru ini terdapat pasal yang mengatur kebolehan aborsi KTD akibat perkosaan, yakni pasal 75 ayat 2. Meskipun demikian, dalam praktek, materi undang-undang tersebut menimbulkan berbagai reaksi dan kontroversi di berbagai lapisan masyarakat.

\section{b.Struktur Materi Hukum}

Menurut UU No. 36 Tahun 2009 tentang Kesehatan, setiap orang dilarang melakukan aborsi, namun larangan tersebut tidak 
berlaku jika ada indikasi kedaruratan medis, seperti kesehatan ibu dan janin terancam, atau kehamilan dalam kasus perkosaan. Persyaratan aborsi ini dilakukan pada usia kehamilan maksimal enam minggu dihitung dari hari pertama haid terakhir, termasuk di dalamnya aborsi dari KTD akibat perkosaan. Sementara itu, jika ada indikasi kedaruratan medis, maka usia maksimal kehamilan tidak berlaku - dengan kata lain, pada keadaan ini, aborsi kapanpun dapat dilakukan. Dengan demikian, pelayanan aborsi legal karena ada indikasi kedaruratan medis dirasa tidak ada masalah (Amnesty International, 2010: 8).

Lain halnya dengan aborsi kehamilan akibat perkosaan, hal ini mengingat pemberian aborsi legal hanya diizinkan dalam waktu enam minggu dihitung dari hari pertama haid terakhir. Pemberian izin aborsi dalam waktu enam minggu dihitung dari hari pertama haid terakhir, tentu tidak sama dengan enam minggu usia kehamilam. Hal ini dikarenakan masa subur seorang perempuan (ovulasi) itu sekitar 6-11 hari setelah haidmasa subur ini ditentukan oleh siklus haid masing-masing perempuan. Jadi, kehamilan akan terjadi hanya ketika berhubungan intim pada masa subur ini. Dengan demikian, penggunaan waktu maksimal aborsi enam minggu dihitung dari hari pertama haid terakhir, sama artinya dengan lima minggu usia kehamilan. Dalam jarak waktu yang terbatas ini tentu membuat korban perkosaan tidak bisa mendapatkan aborsi yang aman. Hal ini dikarenakan kemungkinan adanya ketidaktahuan bahwa mereka telah hamil pada saat itu. Dalam kondisi ini, korban perkosaan tentu memerlukan waktu yang lebih lama untuk mengakui dan melaporkan kepada pihak yang berwenang bahwa mereka telah diperkosa, apalagi ditambah latar belakang yang menstigmakan negatif terhadap seks di luar nikah (Amnesty International, 2010: 9).

Selain itu, dalam UU No. 36 Tahun 2009 tentang Kesehatan, untuk mendapatkan layanan aborsi yang sah terhadap kehamilan yang mengancam nyawa ibu atau janin, maka undang-undang kesehatan menuntut adanya persetujuan dari suami. Dengan kata lain, seorang perempuan tidak diizinkan undang-undang kesehatan ini untuk mendapatkan layanan aborsi yang sah di Indonesia, kecuali jika dia memiliki suami, dan suaminya menyetujui. Ketetapan yang menyangkut adanya persetujuan suami ini tentu bersifat diskriminatif. Hal ini membuktikan bahwa ketetapan ini mengabaikan perempuan dan gadis yang tidak menikah dari pelayanan aborsi aman yang sah. Dengan demikian, materi UU No. 36 Tahun 2009 tentang Kesehatan ini tidak sejalan dengan latar belakang pembentukan undang-undang tersebut.

Dalam latar belakang pembentukan uu kesehatan ini dinyatakan "bahwa setiap kegiatan dalam upaya untuk memelihara dan meningkatkan derajat kesehatan masyarakat yang setinggi-tingginya dilaksanakan berdasarkan prinsip nondiskriminatif, partisipatif, dan berkelanjutan dalam rangka pembentukan sumber daya manusia Indonesia, serta peningkatan ketahanan dan daya saing bangsa bagi pembangunan nasional. Lihat menimbang poin $b$ dalam Undang-Undang Republik Indonesia Nomor 36 Tahun 2009 tentang Kesehatan. Selain bertentangan dengan latar belakang pembentukan uu ini, Pasal 76 poin d ini juga bertentangan dengan Pasal 2 , yang berisi tentang asas dan tujuan uu kesehatan tersebut, yaitu bahwa "Pembangunan kesehatan diselenggarakan dengan berasaskan perikemanusiaan, keseimbangan, manfaat, pelindungan, penghormatan terhadap hak dan kewajiban, keadilan, gender dan nondiskriminatif dan norma-norma agama.

Mengenai kemunculan undang-undang kesehatan yang baru ini beserta materinya, berdasarkan penelitian Amnesty International, banyak ketidaktahuan di antara perempuan dan gadis dari komunitas miskin dan termarginalisasi mengenai aturan baru yang berkaitan dengan pengecualian diperbolehkannya aborsi bagi korban perkosaan dalam UU No. 36 Tahun 2009 tentang Kesehatan ini. Selain mereka, ketidaktauan juga ada pada diri para pekerja kesehatan, seperti dokter. Sebagaimana yang diwawancarai oleh Amnesty International pada bulan Maret 2010, bahwa pekerja kesehatan umumnya hanya mengetahui adanya satu pengecualian aborsi, yaitu layanan aborsi sah yang berkaitan dengan kesehatan ibu atau janin. Sementara pengecualian yang berhubungan dengan 
layanan aborsi sah untuk korban perkosaan, rata-rata mereka tidak mengetahui. Selain mereka, ketidaktauan tentang ketentuan baru ini juga ada pada diri pejabat pemerintah (Amnesty International, 2010: 9). Dengan adanya kenyataan di atas, menunjukkan kurangnya sosialisasi atas materi UU No. $36 \mathrm{Ta}-$ hun 2009 tentang Kesehatan.

\section{c.Kontroversi atas Materi Hukum}

Dalam konteks pengaturan aborsi, materi UU No. 36 Tahun 2009 tentang Kesehatan, khususnya yang mengatur tentang aborsi, menuai kontroversi yang berkepanjangan. Di satu pihak dianggap memasung kebebasan perempuan, dan di sisi yang lain juga terdapat sekelompok kecil yang menganggap sebagai bentuk ketidakhormatan kepada manusia. Di antara dua pandangan tersebut, tidak sedikit juga masyarakat yang mendukung adanya undang-undang tersebut. Hal ini mungkin menimbulkan kontroversi, karena cara pandang yang digunakan oleh masing-masing kelompok berbeda satu sama lain, seperti agama, feminisme, HAM, dan lain sebagainya.

Dengan menggunakan kacamata feminisme, maka undang-undang tersebut dianggap memasung kebebasan perempuan. Hal ini dikarenakan untuk mendapatkan layanan aborsi yang sah terhadap kehamilan yang mengancam nyawa ibu atau janin, maka uu kesehatan menuntut adanya persetujuan dari suami. Hal ini tentu membuat seorang perempuan tidak mendapatkan kebebasan atas dirinya. Sementara itu, jika menggunakan kacamata HAM, maka pelegalan aborsi sebagaimana yang diatur dalam uu tersebut, tentu bertentangan dengan Undang-Undang Hak Asasi Manusia Pasal 53, yang menyatakan bahwa mengenai hak hidup anak dari mulai janin sampai dilahirkan. Demikian juga, jika menggunakan kacamata agama, maka aborsi dianggap sebagai bentuk ketidakhormatan kepada manusia. Dalam hal ini melanggar prinsip mașlaḥah, yaitu hifž al-nafs. Namun, hal tersebut tentu berbeda dengan kasus aborsi dari KTD akibat perkosaan, sebagaimana yang diatur dalam uu tersebut. Selain banyak yang menentang, namun ada juga sebagian masyarakat yang mendukung adanya uu tersebut. Hal ini dikarenakan undang-undang tersebut memberikan solusi yang tepat bagi perempuan yang hamil akibat perkosaan. Bertolak dari berbagai cara pandang di atas, maka terilihat bahwa masih banyak terjadi kontroversi terhadap materi UU No. 36 Tahun 2009 tentang Kesehatan, khususnya tentang pengaturan aborsi KTD akibat perkosaan.

\section{Analisis atas Struktur Materi Hukum Abor- si bagi Korban Perkosaan dalam UU No. 36 Tahun 2009 Tentang Kesehatan dengan Tinjauan Mașlaḥah al-Ṭūfĩ}

Sebagaimana telah terurai pada bab sebelumnya, bahwa ketentuan tentang hukum aborsi di dalam hukum positif di Indonesia diatur di dalam KUHP (Lex Generalis) dan Undang-Undang Kesehatan (Lex Spesialis)_dalam hal ini UU No. 23 Tahun 1992, kemudian diamandemen dengan UU No. 36 Tahun 2009 (Supriyadi, 2001: 12). Ketentuan dalam KUHP, aborsi tidak diperbolehkan dengan alasan apapun dan oleh siapapun juga. Sementara itu, berdasarkan UU No. 23 Tahun 1992 tentang Kesehatan, aborsi diperbolehkan apabila terdapat indikasi medis dalam keadaan darurat dan untuk menyelamatkan jiwa ibu Guttmacer Institute, 2008). Kemudian dalam UU No. 36 Tahun 2009 tentang Kesehatan, permasalahan aborsi lebih memperoleh legitimasi dan penegasan, karena terdapat pasal yang mengatur tentang diperbolehkannya aborsi bagi korban perkosaan.

Mengingat ketentuan dalam KUHP, tindakan aborsi-apapun alasannya- merupakan suatu tindakan pidana, baik bagi pelaksana aborsi (seperti tenaga medis, dukun atau orang lain), wanita yang diaborsi, maupun orang yang terlibat secara langsung terhadap aborsi (Lihat, KUHP Pasal 283, 299, 346, 347, 348, 349, dan 340). Dalam pada itu, wawancara Amnesty International terhadap para pekerja kesehatan, mengisyaratkan bahwa, adanya ancaman kriminalisasi tersebut memiliki efek penghambat besar bagi profesi kesehatan dalam memberikan pelayanan (Amnesty International, 2010: 9). Dengan demikian, jika ada ancaman kriminalisasi- 
sebagaimana yang tersebut dalam KUHPmereka akan enggan melakukan pelayanan aborsi. Sementara itu, berfikir menggunakan logika a contrario, dengan mendekriminalisasi aborsi di Indonesia, maka pelayanan aborsi yang aman akan lebih mungkin diakses oleh para perempuan. Para dokter di Indonesia akan lebih mungkin memberikan pelayanan aborsi dalam kasus di mana mereka memang dimaksudkan untuk memberikan layanan itu. Bertolak dari fakta di atas, maka untuk mendapatkan pelayanan aborsi yang aman, seharusnya pekerja kesehatan jangan ditakuttakuti dengan ancaman pidana, sebagaimana yang tersebut dalam KUHP. Dengan mengutip ungkapannya Satjipto Rahardjo, bahwa jika terjadi problematika hukum, maka hukumlah yang harus ditinjau dan diperbaiki, bukan manusianya yang dipaksa-paksa untuk dimasukan ke dalam skema hokum (Rahardjo, 2005, 2007).

Untuk itu, dalam hal ini, pemerintah perlu melakukan upaya pembaharuan peraturan KUHP, yang mulanya menganggap aborsi sebagai tindakan kriminal, maka mengubahnya menjadi dekriminalisasi (Arief, 1994: 37). Dekriminalisasi di sini, tentu dengan catatan tertentu, yaitu bukan untuk semua pelaku aborsi, namun pemerintah harus mengkhususkan bagi pelaku aborsi dalam keadaan darurat, termasuk di dalamnya aborsi KTD akibat perkosaan (Amnesty International, 2010: 8-10).

Sementara itu, pengaturan normatif legal formal aborsi berdasarkan UU No. 23 Tahun 1992 tentang Kesehatan, khususnya pasal 15, telah terjadi kontradiktif antara aturan dan penjelasannya. Di mana dalam aturannya, aborsi diperbolehkan jika ada indikasi medis tertentu, sementara dalam penjelasannya, tindakan medis dalam bentuk pengguguran kandungan dengan alasan apapun dilarang. Dengan adanya fakta bahwa Pasal 15 dalam UU No. 23 Tahun 1992 tentang Kesehatan ini tidak adanya kejelasan, keserbatercakupan dan keterpaduan antara ketentuan yang satu dengan yang lainnya, berarti aturan tersebut dinilai ambigu dan bertentangan dengan prinsip pembuatan suatu undang-undang, yaitu clear, complete, and coherent (Anggraini, 2007: 542). Selain itu, dengan adanya fakta bahwa sampai sekarang PP (Peraturan Pelaksana) dari UU No. 23 Tahun 1992 tentang Kesehatan tersebut belum dibentuk, berarti ada keragu-raguan pemerintah dalam menangani persoalan aborsi.

Selanjutnya, karena UU No. 23 Tahun 1992 tentang Kesehatan dinilai sudah tidak sesuai lagi dengan perkembangan, tuntutan, dan kebutuhan hukum dalam masyarakat, maka UU tersebut diamandemen dengan undang-undang kesehatan yang baru, yaitu UU No. 36 Tahun 2009 tentang Kesehatan. Dalam pada itu, perbedaan yang signifikan dalam pengaturan aborsi antara kedua undang-undang kesehatan tersebut adalah, bahwa dalam undang-undang kesehatan yang baru, secara eksplisit memperbolehkan aborsi karena KTD akibat perkosaan. Hal itu dinyatakan dalam pasal 75 ayat 2 UU No. 36 Tahun 2009 tentang Kesehatan. Di sana dinyatakan bahwa aborsi dapat dikecualikan bagi "kehamilan akibat perkosaan yang dapat menyebabkan trauma psikologis bagi korban perkosaan".

Ketentuan dengan kalimat tersebut tentu masih menimbulkan pertanyaan, apakah diperbolehkannya aborsi hanya bagi korban perkosaan yang dapat menyebabkan trauma psikologis saja? Lalu, bagaimanakah ukuran dari trauma psikologis tersebut? Hal ini tentu perlu mendapatkan penjelasan lebih lanjut, namun hal ini tidak tersentuh dalam penjelasan resmi atas undang-undang tersebut. Selain itu, dalam ketentuan pasal 75 ayat 4, menyebutkan bahwa ketentuan lebih lanjut mengenai hal tersebut, sebagaimana dengan Peraturan Pemerintah, namun sampai sekarang PP belum dikeluarkan.

Lebih lanjut, aborsi bagi korban perkosaan ini dapat dilakukan sebelum enam minggu usia kehamilan, dihitung dari hari pertama haid terakhir. Sebagaimana yang telah dibahas sebelumnya, bahwa waktu enam minggu dihitung dari haid terakhir ini, sama artinya dengan lima minggu usia kehamilan. Hal ini dikarenakan masa subur seorang wanita (ovulasi), agar terjadi kehamilan adalah sekitar 6-11 hari setelah haid. Pemberian waktu ini, tentu memerlukan alasan, mengapa aborsi hanya diperbolehkan 
sebelum waktu enam minggu dihitung dari haid terakhir. Namun, alasan ini juga tidak ditemukan dalam penjelasan resmi atas undang-undang tersebut.

Pada prinsipnya, tujuan penetapan hukum adalah untuk kemasalahatan manusia. Demi terwujudnya kemaslahatan tersebut, maka ada lima hal yang harus terpelihara, atau biasa didistilahkan dengan al-ușūl al -khamsah (Al-Gazalī, 1980: 174). Kelima hal tersebut yaitu, memelihara agama (hifz aldīn), memelihara jiwa (hifz al-nafs), memelihara akal (hifz al-aql), memelihara keturunan (hifz al-nasl), dan memelihara harta (hifz al-māl). Kelimanya tersebut dapat dibedakan menjadi tiga peringkat, yakni ḍarūriyyah, hâajjiyyah, dan taḥsinniyyah. Sementara itu, jika antara antar mașlaḥah dan mafsadah terdapat pada satu persoalan, maka jalan keluar yang ditempuh adalah merinci kepentingan mașlahahah-nya dan menghindari efek buruk (mafsadah) jika itu memungkinkan.

Demikian pula saat terdapat pertentangan antar mașlaḥah atau di antara mafsadah yang ada maka bagi al-Ṭūfī mengunggulkan salah satunya, dan jika keduanya sepadan maka pilih salah satu (al-Ṭūfī, 1980: 46). Pertanyaannya kemudian, bagimana dengan pengaturan aborsi yang ada dalam UU No. 36 Tahun 2009 tentang Kesehatan. Di satu sisi, terdapat perempuan yang menderita akibat hamil yang tidak dikehendaki sebab perkosaan, di sisi lain terdapat bayi dalam kandungan yang harus dijaga keselamatan nyawanya karena ia juga memiliki hak hidup. Di sini terdapat problem berupa berkumpulnya kemaslahatan si perempuan dan kemafsadatan si anak jika dilakukan aborsi.

Berdasarkan kepentingannya, memelihara agama (hifž al-dīn) dapat dibedakan menjadi tiga peringkat. Pertama, memelihara agama dalam peringkat ḍaūriyyah, yaitu memelihara dan melaksanakan kewajiban keagamaan yang termasuk peringkat primer. Kedua, memelihara agama dalam peringkat hājiyyah, yaitu melaksanakan ketentuan agama dengan maksud menghindari kesulitan. Ketiga, memelihara agama dalam peringkat tahsininiyyah, yaitu mengikuti petunjuk agama guna menunjung tinggi martabat manusia. Dalam prinsip mașlaḥah hifž al-dīn ini, jika dikaitkan dengan aborsi secara umum, maka perbuatan ini akan melanggar prinsip mașlaḥah hifž al-dīn, khususnya dalam peringkat darūriyyah. Hal ini wajar karena mengingat dosa besar yang ditimbulkan dari aborsi tersebut. Namun, tentu hal ini berbeda dengan aborsi KTD akibat perkosaan, yang diatur dalam UU No. 36 Tahun 2009 tentang Kesehatan. Aborsi dalam keadaan ini dapat menghindarkan kesulitan bagi perempuan korban perkosaan. Sementara jika janin tetap dibiarkan hidup di dalam kandungan, sampai ia lahir, maka akan menimbulkan kesulitan bagi kehidupan perempuan tersebut. Dengan demikian, aborsi KTD akibat perkosaan termasuk memelihara agama dalam peringkat hājijyyah.

Hal yang perlu diperhatikan kedua untuk mewujudkan kemaslahatan adalah memelihara jiwa (hifž al-nafs). Berdasarkan tingkat kepentingannya, dapat dibedakan menjadi tiga peringkat. Pertama, memelihara jiwa dalam peringkat ḍarūriyyah. Jika peringkat ḍarūriyyah ini diabaikan, maka eksistensi jiwa manusia akan terancam, dan ini dilarang oleh Allah Swt. Kedua, memelihara jiwa dalam peringkat hājiyyah. Jika kegiatan ini diabaikan, maka tidak akan mengancam eksistensi manusia, melainkan dalam peringkat ini hanya mepersulit hidupnya. Ketiga, memelihara jiwa dalam peringkat tahsīniyyah. Kegiatan ini hanya berhubungan dengan kesopanan dan etika, sama sekali tidak akan mengancam eksistensi jiwa manusia, ataupun mempersulit kehidupan seseorang.

Dalam prinsip mașlaḥah hifz al-nafs ini, jika dikaitkan dengan aborsi, maka jelas akan bertentangan dengan prinsip mașlaḥah ini. Dalam aborsi, tentu hanya jiwa ibu yang diselamatkan, sementara jiwa anak sengaja dimusnahkan. Dengan demikian, aborsi melanggar prinsip mașlaḥah memelihara jiwa, khususnya dalam peringkat ḍarūriyyah. Namun, lain halnya dengan aborsi KTD akibat perkosaan, yang diatur dalam UU No. 36 Tahun 2009 tentang Kesehatan, maka perbuatan ini berhubungan dengan keselamatan jiwa ibu dan anak. Dalam aborsi ini, tentu jiwa ibu yang diselamatkan, sementara jiwa anak sengaja dimusnahkan. Hal ini dapat dimaklumi karena, jika anak tersebut 
dilahirkan justru akan menimbulkan kesulitan bagi perempuan korban perkosaan. Dengan demikian, aborsi KTD akibat perkosaan termasuk memelihara jiwa dalam peringkat hājizyyah.

Selanjutnya, prinsip mașlaḥah yang ketiga adalah memelihara akal (hifż al-aql). Dilihat dari segi kepentingannya, memelihara akal dapat dibedakan menjadi tiga peringkat. Pertama, memelihara akal dalam peringkat darūriyyah. Contohnya adalah diharamkannya meminum minuman keras. Jika ketentuan ini tidak diindahkan maka akan berakibat pada terancamnnya eksistensi akal dan merupakan perbuatan dosa. Kedua, memelihara akal dalam peringkat hājijiyyah, seperti dianjurkan untuk menuntut ilmu pengetahuan. Sekiranya kegiatan ini tidak dilakukan, maka tidak akan merusak akal, tetapi akan mempersulit kehidupan seseorang dalam kaitannya mengembangkan ilmu pengetahuan.

Ketiga, memelihara akal dalam peringkat tahsinniyyah, seperti menghindarkan diri dari menghayal atau mendengarkan sesuatu yang tidak bermanfaat. Hal ini erat kaitannya dengan etika dan tidak akan mengancam eksisitensi akal secara langsung. Dalam prinsip mașlahah hifz al-aql ini, jika dikaitkan dengan aborsi, maka perbuatan ini berhubungan dengan beban psikis si perempuan yang mengandung. Bisa jadi dia akan selalu terbayang-bayang akan perbuatannya yang tidak manusiawi terhadap darah dagingnya sendiri, bahkan bisa stress akut. Dengan demikian, aborsi melanggar prinsip mașlahah dalam memelihara akal, khususnya dalam peringkat darūriyyah. Namun, jika prinsip mașlah̆ah hifż al-aql ini, jika dikaitkan dengan aborsi KTD akibat perkosaan, yang diatur dalam UU No. 36 Tahun 2009 tentang Kesehatan, maka perbuatan ini berhubungan dengan beban psikis yang akan ditanggung perempuan korban perkosaan. Jika aborsi dilakukan, maka paling tidak dapat mengurangi beban psikis tersebut. Dengan demikian, aborsi KTD akibat perkosaan termasuk memelihara akal dalam peringkat ḍarūriyyah.

Prinsip mașlaḥah yang keempat adalah memelihara keturunan (hifz al-nasl). Dilihat dari segi kebutuhannya, dapat dibedakan menjadi tiga peringkat. Pertama, memelihara keturunan dalam peringkat d̦arūriyyah. Untuk kelangsungan kehidupan manusia perlu adanya keturunan yang jelas dan sah. Jika ini diabaikan, maka akan mengancam eksistensi keturunan. Kedua, memelihara keturunan dalam peringkat hājjïyyah seperti ditetapkan ketentuan menyebutkan mahar bagi suami pada waktu akad nikah dan diberikan hak talak baginya. Jika hal ini diabaikan, maka akan mengalami kesulitan. Ketiga, memelihara keturunan dalam peringkat tahsiniyyah, seperti disyariatkan khițbah dan atau walīmah dalam perkawinan. Jika hal ini diabaikan, maka tidak akan mengancam eksistensi keturunan, dan tidak pula mempersulit orang yang melakukan perkawinan. Dalam prinsip mașlahah hifž al-nasl ini, jika dikaitkan dengan aborsi, maka perbuatan ini mengancam eksistensi keturunan. Dengan demikian, aborsi melanggar prinsip mașlahah memelihara keturunan, khususnya dalam peringkat d̦arūriyyah.

Dalam prinsip mașlaḥah hifż al-nasl ini, jika dikaitkan dengan aborsi KTD akibat perkosaan, yang diatur dalam UU No. 36 Tahun 2009 tentang Kesehatan, maka perbuatan ini berhubungan dengan status anak yang lahir dari korban perkosaan. Jika anak tetap dilahirkan, maka ia hanya punya hubungan nasab dengan ibunya. Dengan demikian, aborsi KTD akibat perkosaan termasuk memelihara keturunan dalam peringkat darūriyyah.

Prinsip mașlahah yang kelima adalah memelihara harta (hifż al-māl). Dilihat dari segi kepentingannya, pemeliharaan harta dapat dibedakan menjadi tiga peringkat. Pertama, memelihara harta dalam peringkat darūriyyah. Untuk mempertahankan kehidupannya manusia memerlukan harta dalam rangka memenuhi kebutuhan hidupnya, sehingga mereka berupaya mendapatkan harta dengan cara yang halal dan baik. Apabila aturan ini dilanggar, maka akan berakibat terancam eksistensi harta Kedua, memelihara harta dalam peringkat hājjiyyah, seperti disyariatkannya jual-beli salam, kerjasama dalam pertanian (muzara ah) dan perkebunan (musāqah) serta perdagangan (muḍārabah).

Apabila cara ini tidak dilaksanakan, 
maka tidak akan mengancam eksistensi harta, melainkan akan mempersulit orang yang memerlukan modal. Ketiga, memelihara harta dalam peringkat tahsinniyyah seperti adanya ketentuan agar menghindarkan diri dari pengecohan dan penipuan. Hal ini erat kaitannya dengan etika bermuamalah atau etika berbisnis, serta akan mempengaruhi kesahan jual-beli, sebab peringkat yang ketiga ini juga merupakan syarat adanya peringkat yang kedua dan pertama. Dalam prinsip mașlaḥah hifẓ al-māl ini, jika dikaitkan dengan aborsi, maka perbuatan ini justru malah menganggarkan harta hanya untuk perbuatan yang sia-sia. Hal ini wajar mengingat biaya aborsi yang mahal, apalagi jika dilakukan oleh tenaga medis yang tidak profesional, justru akan menimbulkan berbagai penyakit. Dengan demikian, aborsi melanggar prinsip mașlaḥah memelihara keturunan, khususnya dalam peringkat darūriyyah .

Dalam prinsip mașlaḥah hif̣̣ al-māl ini, jika dikaitkan dengan aborsi KTD akibat perkosaan, yang diatur dalam UU No. $36 \mathrm{Ta}-$ hun 2009 tentang Kesehatan, maka perbuatan ini berhubungan dengan beban ekonomi. Jika anak tetap dilahirkan, maka beban ekonomi yang besar akan ditanggung oleh si ibu korban perkosaan untuk mengasuh anaknya. Lebih-lebih, di Indonesia saat ini belum ada jaminan penuh atas kesejahteraan bagi bayi yang baru lahir. Dengan demikian, aborsi KTD akibat perkosaan termasuk memelihara harta dalam peringkat darūriyyah.

Bertolak dari kelima kemaslahatan di atas, jika dihubungkan dengan aborsi, maka perbuatan tersebut telah melanggar kelima prinsip mașlaḥah, khususnya dalam peringkat darūriyyah. Artinya, jika aborsi dilakukan, maka akan berakibat terancamnya eksistensi kelima pokok mașlaḥah di atas. Dengan demikian, aborsi merupakan perbuatan yang menimbulkan mafsadah. Namun, lain halnya dengan aborsi KTD akibat perkosaan, yang diatur dalam UU No. 36 Tahun 2009 tentang Kesehatan, maka perbuatan ini justru lebih banyak mendatangkan mașlaḥah dari pada mafsadah. Dengan demikian, ada pengecualian aborsi dalam kondisi ini. Untuk membenarkan tindakan mengambil resiko buruk untuk mempertahankan kepentingan yang lebih utama itu ulama menggunakan kaidah, "Kedaruratan itu membolehkan adanya larangan" (al-Asmurī, 2002: 102).

Mengetahui peringkat mașlaḥah dalam kelima pokok kemaslahatan di atas menjadi penting untuk dihubungkan dengan skala prioritas penerapannya. Ketika kemaslahatan yang satu berbenturan dengan kemasalahatan yang lainnya. Dalam hal ini tentu peringkat pertama, ḍaūriyyah, harus didahulukan daripada peringkat kedua, hājjizyah, dan peringkat ketiga, tahsiniyyah. Ketentuan ini menunjukkan bahwa dibenarkan mengabaikan halhal yang termasuk peringkat kedua dan ketiga manakala kemaslahatan peringkat pertama terancam eksistensinya. Jadi, harus didahulukan memelihara jiwa dalam peringkat ḍaūriyyah daripada peringkat hājjjiyyat. Begitu pula halnya dalam peringkat tahsinniyyah berbenturan dalam peringkat hājjiyyah harus didahulukan dari pada tahsininiyyah.

Keadaan di atas hanya pada yang berbeda peringkat. Adapun kasus yang peringkatnya sama, seperti peringkat darūriyyah dengan peringkat darūriyyah namun berbeda dalam urutan kepentingannya didahulukan urutan yang lebih tinggi. Bila kepentingan memelihara agama berbenturan dengan kepentingan memelihara jiwa, maka didahulukan memelihara agama. Dalam menyelesaikan adanya benturan-benturan pada tingkat d̦arūriyyah ini para pakar menetapkan kaidah yang berbunyi, "Kemudaratan yang lebih besar dapat dihilangkan dengan kemudaratan yang lebih kecil" (Zahrah, 1958: 127).

Selanjutnya dapat dilihat bila kelima bentuk ḍarūriyyah itu berbenturan, prioritas pertama yang harus dipelihara, yaitu agama kemudian jiwa, setelah itu keturunan, serta akal, dan terakhir harta. Untuk membenarkan tindakan mengambil resiko buruk untuk mempertahankan kepentingan yang lebih utama itu ulama menggunakan kaidah, "Kedaruratan itu membolehkan adanya larangan" (al-Asmurī, 2000: 102). Untuk mencapai pemeliharaan terhadap lima unsur yang pokok secara sempurna, maka ketiga tingkatan ini tidak dapat dipisahkan. Sejalan dengan itu adalah komentar al-Syāțibī, "Jika ketentuan tersebut telah dipahami, maka orang yang 
berakal tidak ragu bahwa perkara yang bersifat hājjijyyah adalah bagian yang berkisar pada perkara-perkara d̦arūriyyah, yang merupakan tujuan pokok. Begitu juga perkaraperkara yang bersifat tahsiniyyah adalah bagiannya, sebab ia pelengkap bagi hājjìyyah, sementara hājjjiyyah itu pelengkap d̦arūriyyah. Ini berarti tahsiñiyyah merupakan pelengkap d̦arūriyyah. Karena itu, secara otomatis tujuan yang bersifat pelengkap (tahsininiyyah) ini adalah bagian yang primer (darūriyyah) dan sebagai pelengkap (Al-Syāțibī, 1997: II/25-26). Keterangan ini menunjukkan keuniversalan kemaslahatan yang pemeliharaan dan penegakkannya menjadi tujuan syariah. Kemasalahatan itu tidak hanya bersifat duniawi, material, dan individual, tetapi yang dimaksud adalah kemaslahatan yang menjadi pondasi tegaknya syariah, baik dalam bentuk totalitas ataupun parsial, ia juga merupakan kemaslahatan yang memperhatikan kepentingan dunia dan akhirat dan keseimbangan individu dan masyarakat.

\section{Simpulan}

Pengaturan aborsi bagi korban perkosaan di Indonesia telah diatur dalam UU No. 36 Tahun 2009 tentang Kesehatan. Di dalamnya dikatakan bahwa setiap orang dilarang melakukan aborsi, namun larangan tersebut tidak berlaku jika ada indikasi kedaruratan medis, seperti kesehatan ibu dan janin terancam, atau kehamilan dalam kasus perkosaan. Persyaratan aborsi ini dilakukan pada usia kehamilan maksimal enam minggu dihitung dari hari pertama haid terakhir, termasuk di dalamnya aborsi dari KTD akibat perkosaan. Sementara itu, jika ada indikasi kedaruratan medis, maka usia maksimal kehamilan tidak berlaku dengan kata lain, pada keadaan ini, aborsi kapanpun dapat dilakukan. Dengan demikian, pelayanan aborsi legal karena ada indikasi kedaruratan medis dirasa tidak ada masalah, karena dalam kondisis ini, aborsi kapanpun dapat dilakukan. Lain halnnya dengan aborsi kehamilan akibat perkosaan, hal ini mengingat pemberian aborsi legal hanya diizinkan dalam waktu enam minggu dihitung dari hari pertama haid terakhir. Dalam jarak waktu yang terbatas ini tentu membuat korban perkosaan tidak bisa mendapatkan aborsi yang aman. Hal ini dikarenakan kemungkinan adanya ketidaktahuan bahwa mereka telah hamil pada saat itu.

Secara prinsipil materi hukum aborsi bagi korban perkosaan yang diatur dalam UU No. 36 Tahun 2009 tentang Kesehatan sejalan dengan konsep mașlaḥah yang digagas oleh al-Ṭūfĩ. Namun demikian, adanya batasan usia kehamilan maksimal enam minggu dihitung dari hari pertama haid terakhir menjadi hal yang menyebabkan undang-undang tersebut tidak lagi sejalan dengan konsep mașlaḥah al-Ṭūfī. Ketidakselarasan ini disebabkan adanya kemungkinan kondisi psikis yang dialami oleh perempuan hamil korban perkosaan yang mengakibatkan ketidaktahuan awal kehamilan. Dalam arti, bisa jadi perempuan tersebut baru mengetahui kehamilannya melebihi batas waktu tersebut. Namun demikian, kebolehan ini juga harus melalui pertimbangan-pertimbangan perbandingan kemaslahatan dan kemafsadatan yang ada sesuai dengan kasusnya masing-masing.

\section{Daftar Pustaka}

Al-Asmurī, Șāliḥ bin Muḥammad, 2000. Majmūat alFawā'id al-Bahiyyah 'alā Manz̧ūmah al-Qawā'id al-Bahiyyah, T.T.p.: Dār al-Șamīì.

Al-Būțī, Muḥammad Sa Īd Ramaḍān, Dawābiț alMașlaḥah fī al-Syarīah al-Islāmiyyah, Kairo: Mu'assasah al-Risālah, 1965.

Al-Būțī, Mas'alah Taūdīd al-Nasl: Wiqāyatan wa 'llājan, Syiria: Maktabah al-Farabī, 2000.

Al-Gazalī, Abū Ḥāmid Al-Muștasfā fī 'Illm al-Ușūl (Beirut: Dār al-Kutub al-`Ilmiyyah, 1980.

Ali, Atabik dan Ahmad Zuhdi Muhdlor, Kamus Kontemporer Arab-Indonesia, Yogyakarta: Multikarya Grafika, 1999.

Al-Jawziyyah, Ibn al-Qayyim, A lām al-Muwaqqi'īn, Beirut: Dār al-Jalīl, 1973.

Al-Salam, Izzuddin bin Abd, 1994. Qawā̄id al-Ahkām fī Mașāliḥ al-An ām (Kairo: Maktabah al-Kuliyyah al-Azhariyah.

Al-Suyuțī, Jalāluddīn `Abd al-Raḥmān, t.th. Al-Asybah wa al-Naz̧ā'ir, Surabaya: al-Hidayah.

Al-Syāțib̄̄, Abū Isḥāq Ibrāhim Ibn Muḥammad, AlMuwāfaqāt fĩ Ușūl al-Syarīah, Beirut: Dār Ibn 
'Affān, 1997.

Al-Ṭūfī, Najm al-Dīn Sulaimān bin `Abd al-Qawiy, Syarḥ al-Arba'in al-Nawawiyyah, Beirut: Dār al-Fikr, t.th.

Al-Ṭūfī, Syarḥ Mukhtașar Rawọah al-Nāẓir, Saudi Arabiyah: Mamlakah al-'Arabiyyah, al-'Audiyyah, 1998.

Al-Ṭūfī, Risālah fi Ri āyah al-Mașlaḥah, T.t.t.: al-Dār alMișriyyah, 1993.

Amnesty Internasional, Tak Ada Pilihan, Rintangan atas Kesehatan Reproduktif di Indonesia: Ringkasan Eksekutif (London: Amnesty International Publication, 2010).

Anggraini, L., 2007. Aborsi dalam Pandangan Hukum Islam dan Hukum Positif di Indonesia, dalam Jurnal Hukum Islam, Vol. VII, No. 5, Juli, hlm. 537

Bakar, Al Yasa Abu (1991). "Fiqh Islam dan Rekayasa Sosial", dalam Ari Anshori dan Slamet Warsidi (ed.), Figh Indonesia dalam Tantangan, Surakarta: FAI UMS, 1991.

Ciciek, F. 2002. "Perkosaan Terhadap Perempuan di Ruang Domestik dan Publik", dalam S. Edi Santosa, Islam dan Konstruksi Seksualitas, Yogyakarta: Pustaka Pelajar.

Ebrahim, Mohsin AF., 1998. Aborsi, Kontasepsi, dan Mengatasi Kemandulan: Isu-isu Biomedis dalam Perspektif Islam, terj. Sari Meutia, Bandung: Mizan.

Ekotomo, Suryono (dkk.), 2000. Abortus Provokatus Bagi Korban Perkosaan: Perspektif Viktimologi Kriminologi dan Hukum Pidana, Yogyakarta: Universitas Atmajaya Press.

Guttmacer Institute, 2008. Aborsi di Indonesia, No. 2, hlm. 1.

Hallaq, Wael b., 2000. Sejarah Teori Hukum Islam: Pengantar Untuk Ushul Figh Madzab Sunni, terj. Abdul Haris, Jakarta: PT. Raja Grafindo Persada.

Hāsyimah, Kāmil Iskandar. 2003. Al-Munjid al-Wasịt fī al- 'Arabiyyah al-Mu āșirah, Beirut: Libanon, Dār al-Masyriq.

Indraswari, 1999. "Fenomena Kawin Muda dan Aborsi: Gambaran Kasus", dalam Syafiq Hasyim (ed.), Menakar "Harga" Perempuan, Bandung: Mizan. Institute, Gutmacher, Aborsi di Indonesia, New York: Gutmacher Institute, 2008

Internasional, Amnesty, Tak Ada Pilihan, Rintangan atas Kesehatan Reproduktif di Indonesia: Ringkasan Eksekutif, London: Amnesty International Publication, 2010.

Istibsjaroh, 2007. Menimbang Hukum Pornografi, Pornoaksi, dan Aborsi dalam Perspektif Islam, Sura- baya: IAIN Sunan Ampel Press.

Mahjuddin, 2005. Masailul Fiqhiyah Berbagai Kasus yang Dihadapi Hukum Islam Masa Kini, Jakarta: Kalam Mulia.

Manan, A., 2007. Reformasi Hukum Islam Indonesia: Tinjauan dari Aspek Metodologis, Legislasi, dan Yusipudensi, Jakarta: Raja Grafindo Persada.

Muhammad, H., 2002. Fiqh Perempuan: Refleksi Kiai atas Wacana Agama dan Gender, Yogyakarta: LKiS.

Muhammad, H., 2004. Islam Agama Ramah Perempuan: Pembelaan Kiai Pesantren, Yogyakarta: LKiS.

Mumtazah, Afwan dan Yulianti Muthmainnah, 2007. Menimbang Penghentian Kehamilan Tidak Diinginkan: Perspektif Hukum Islam dan Hukum Positif, Jakarta: Rahima.

Munawwir, A. Warson, 2002. Kamus Al-Munawwir: Arab-Indonesia Terlengkap, Surabaya: Pustaka Progressif.

MUI, Himpunan Fatwa Majelis Ulama Indonesia, Jakarta: MUI, 2010.

Nasution, K. 2003. "Pandangan Islam Tentang Aborsi", dalam Musawa: Jurnal Studi Gender dan Islam, Vol. 2.

Rahardjo, S., 2005. "Hukum Progresif: Hukum yang Membebaskan", dalam Jurnal Hukum Progresif, Vol. 1, No. 1, April 2005.

Rahardjo, S., 2007. "Konsep dan Karakteristik Hukum Progresif", Makalah, dalam Seminar Nasional Hukum Progresif I, Diselenggarakan oleh Fakultas Hukum Universitas Diponegoro Bekerjasama dengan Program Doktor Ilmu Hukum Universitas Diponegoro dan Fakultas Hukum Universitas Trisakti, Jakarta di Semarang, 15 Desember 2007.

Supriyadi, "Politik Hukum Kesehatan terhadap Pengguguran Kandungan", Makalah disampaikan dalam Diskusi Ilmiah tanggal 2 Juli 2002, "Aborsi dari kajian Ilmu Politik Hukum" (Hukum Kesehatan dan Hukum Pidana), (Yogyakarta: Bagian Hukum Pidana, FH-UAJY, 2001), hlm. 12.

Tim Partisipasi Masyarakat, 2011. “Dukung Perempuan Korban Kekerasan Seksual", dalam Berita Komnas Perempuan, Edisi 6, Februari, hlm. 4.

Tutik, T. W., 2010. "Analisis Hukum Islam Terhadap Praktik Aborsi Bagi Kehamilan Tidak Diharapkan (KTD) Akibat Perkosaan Menurut UndangUndang No. 36 Tahun 2009 Tentang Kesehatan", Makalah, Semarang: Undip.

Uddin, J., dkk., 2010. Reinterpretasi Hukum Islam Ten- 
tang Aborsi, Jakarta: Universitas Yarsi.

Utomo B (dkk.), 2001. Insidence and Social-Psychological Aspects of Abortion in Indonesia: A Community-Base Survey in 10 Major Cities and 6 Districts, Year 2000 (Jakarta: Pusat Penelitian Kesehataan UI, 2001).

Zahrah, Abū, 1958. Ușūl al-Fiqh, Beirut: Dār al-Fikr.

Zayd, Muștafāā, 1424. Al-Mașlaḥah fī al-Tasyrī’ alIslāmĩ: Risālah 'Ilmiyyah, Kairo: Dār al-Yasar li al-Ṭabā’ah wa al-Nasyar.

Zuhdi, M.,1986. Islam dan Keluarga Berencana di Indonesia, Bina Ilmu: Surabaya.

\section{Website}

"Baru Enam Bulan di Jakarta, Pengasuh Bayi Diperkosa Sopir Angkot", dalam http://www.tempo. co/read/news/2011/10/14/064361333/BaruEnam-Bulan-di-Jakarta-Pengasuh-Bayi-Diperkosa-Sopir-Angkot (Diakses pada tanggal 22 November 2011).

"Bocah Lima Tahun Diperkosa Sopir Angkot ", dalam http://www.tempo.co/read/ news/2011/09/30/064359209/Bocah-LimaTahun-Diperkosa-Sopir-Angkot (Diakses pada tanggal 22 November 2011).

“Diperkosa Ayah Tiri, Siswi SMP Hamil 5 Bulan”, dalam http://www.surya.co.id/2011/07/14/diperkosaayah-tiri-siswi-smp-hamil-5-bulan (Diakses pada tanggal 02 Oktober 2011).

“Diperkosa Hingga Hamil, Seorang Buruh Pabrik di Nganjuk Lapor Polisi", dalam http:// suaramerdeka.com/v1/index.php/read/ news/2011/01/08/75004 (Diakses pada tanggal 02 Oktober 2011).

"DPR: Silahkan UU Kesehatan Dibawa Ke MK", dalam http://matanews.com/2009/10/14/dpr-silahkan-uu-kesehatan-dibawa-ke-mk/ (Diakses pada tanggal 24 November 2011).

"Gadis 9 Tahun Hamil Bayi Kembar Akibat Diperkosa Ayah Tiri", dalam http://www.detiknews.com/ $\mathrm{read} / 2009 / 03 / 02 / 043237 / 1092489 / 10 /$ gadis9-tahun-hamil-bayi-kembar-akibat-diperkosaayah-tiri (Diakses pada tanggal 02 Oktober 2011).

http://www.rifka-annisa.net.co.id (Diakses pada tanggal 16 Oktober 2011).

"Ini di Palembang, Anak Diperkosa Ayah Hingga Hamil", dalam http://makassar.tribunnews. com/2011/07/05/ini-di-palembang-anak-diperkosa-ayah-hingga-hamil, (Diakses pada tanggal 02 Oktober 2011).
"Memperingati Hari Ibu: Mengapa Aki Masih Tinggi Juga?", Harian Kompas, 22 Desember 2003.

"MUI: Korban Perkosaan Boleh Aborsi", dalam http:// www.merdeka.com/pernik/mui-korbanperkosaan-boleh-aborsi-p8ribrd.html (Diakses pada tanggal 24 November 2011).

Muthmainnah, Yulianti, Mengkritisi Undang-Undang Kesehatan Kita, dalam http://www.komnasperempuan.or.id/2010/03/mengkritisi-undangundang-kesehatan-kita/ (Diakses pada tanggal 24 November 2011).

Nelis, Sri, Aborsi dan Hukumnya di Indonesia, dalam http://www.sumbaronline.com/berita-4240-aborsi-dan-hukumnya-di-indonesia--.html (Diakses pada tanggal 24 November 2011).

"Santriwati Itu Diperkosa Sampai Hamil 6 Bulan", dalam http://megapolitan.kompas.com/ $\mathrm{read} / 2010 / 01 / 13 / 14425834 /$ Santriwati.Itu.Diperkosa.Sampai.Hamil.6.Bulan (Diakses pada tanggal 02 Oktober 2011).

"Santri Diperkosa Sampai Hamil Dua Kali", dalam http://nasional.kompas.com/ $\mathrm{read} / 2008 / 11 / 22 / 09091350 /$ santri.diperkosa. sampai.hamil.dua.kali (Diakses pada tanggal 02 Oktober 2011).

"Siswi I SMP Diperkosa Kakak Ipar, Hamil 4 Bulan", dalam http://megapolitan.kompas.com/ read/2010/02/05/09323161/Siswi.I.SMP.Diperkosa.Kakak.Ipar.Hamil.4.Bulan (Diakses pada tanggal 02 Oktober 2011).

Tim Partisipasi Masyarakat, "Dukung Perempuan Korban Kekerasan Seksual", dalam Berita Komnas Perempuan, Edisi 6, Februari, 2011.

"Tokoh Agama Tentang Aturan Aborsi", dalam http:// matanews.com/2009/10/13/tokoh-agama-tentang-aturan-aborsi/ (Diakses pada tanggal 24 November 2011).

"Waduh! Terjadi Lagi Penumpang Angkot Diperkosa Sopir", dalam http://www.republika.co.id/berita/nasional/hukum/11/10/13/lt0g3x-waduh-terjadi-lagi-penumpang-angkot-diperkosa-sopir (Diakses pada tanggal 22 November 2011).

\section{Undang-Undang}

Undang-Undang Repubik Indonesia Nomor 36 Tahun 2009 Tentang Kesehatan

Undang-Undang Repubik Indonesia Nomor 23 Tahun 1992 Tentang Kesehatan

Kitab Undang-Undang Hukum Pidana 